\title{
Effectiveness of Melatonin, as a Radiation \\ Damage-Mitigating Drug in Modulating Liver Biochemical disorders in $\gamma$-Irradiated Rats
}

\author{
N. M. El-Fatih and E. Elshamy \\ Radiation Biology and Health Radiation Research Dept., \\ National Centre for Radiation Research and Technology \\ (NCRRT), P. O. Box: 29 Nasr City, Cairo, Egypt.
}

\begin{abstract}
$\mathrm{M}$ ELATONIN has an antiperoxidative effect on several tissues as well as a scavenger effect on reactive oxygen species (ROS). Whilst radiation-hazards due to free radical generation, present enormous challenges for biological and medical safety. Therefore, rats were classified into four groups; control $(n=8)$, (received $0.5 \mathrm{ml}$ of alchoholic saline as a vehicle for 5 days). Melatonin-treated rats received $10 \mathrm{mg} / \mathrm{kg}$ body wt, for 5 days (given to the animals in the morning via stomach tube). $\gamma$-irradiated rats received $0.5 \mathrm{ml}$ of the melatonin vehicle followed by one shot dose of $3 \mathrm{~Gy} \gamma$-rays. Each of these groups was compared with a further group, which-received melatonin for 5 days after 3 Gy $\gamma$-irradiation exposure. The results revealed that all considered biochemical parameters were not changed significantly in melatonin-treated group as compared with control one. In the liver tissue of the $\gamma$-irradiated animals (3 Gy), the oxidative stress markers malondialdehyde (MDA) and protein carbonyl (PC) were significantly increased, while a marked decrease occurred in the contents of deoxy- \& ribo-nucleic acids (DNA \& RNA) and glutathione (GSH) as well as activity of glutathione-S-transferase (GST). In addition, catalase (CAT) and myeloperoxidase (MPO) activities were increased. Activities of aspartate transaminase (AST), alkaline phosphatase (ALP) and gamma-glutamyltransferase (GGT) were significantly increased in sera of the irradiated rats. Treatment with melatonin for 5 days after $\gamma$-rays exposure significantly modulated the radiation-induced elevations in MDA and PC levels in the liver tissue and significantly restored hepatic GSH content, GST, CAT and MPO activities. Post-irradiation treatment with melatonin showed significant higher hepatic DNA and RNA contents than irradiated rats. The activities of AST, ALP, and GGT in serum were significantly ameliorated when melatonin was administrated after irradiation.

Conclusion: Melatonin has effective mitigating effects against $\gamma$-radiation induced oxidative stress and liver injury. Key words: Melatonin, mitigation, liver, $\gamma$-rays, rats.
\end{abstract}


Based on animal models, radiobiologists have long been interested in identifying novel non-toxic and convenient compounds to protect and/ or mitigate humans from radiation induced normal tissue and organ injuries and to allow the use of higher doses of radiation during radiotherapy for a better curative ratio.

The properties of melatonin suggest that this molecule is an important effector of stress responses. In this way, its actions may counteract or buffer both environmental and endogenous stressors to maintain organ integrity (Slominski1 et al., 2008). Melatonin is distributed ubiquitously throughout an organism because its small size and amphiphilic nature facilitate permeability to all cellular compartments. Moreover, it has pleiotropic bioactivity as a biological-response modifier and in energy expenditure (Pandi-Perumal et al., 2006). Furthermore, melatonin is reported to influence a variety of inflammatory and immune responses (Esposito et al., 2008).

Radiation is a source of exogenous free radicals and these radicals with other radicals damage biological macromolecules (Hannig et al., 2000). Irradiation caused marked decrease in serum melatonin and its pineal biosynthesis (Ahlersova et al., 1998). Total antioxidant capacity of plasma was reduced in rats exposed to whole body $\gamma$-radiation (Zahran et al., 2006). Consequently the cellular antioxidant capacity is decreased and the organs become more susceptible to the deleterious effects of ROS (Karbownik and Reiter, 2000). Similarly, total body irradiation in rats has been reported to cause oxidative tissue damage (Sener et al., 2004). The aim of the present study is to investigate the radiation damage mitigating-role of melatonin (delivered after irradiation) against oxidative stress induced liver injury in rats.

\section{Materials and Methods}

All animal treatment procedures met the guidelines of the National Research Council (1996). The experiments were performed in male rats weighing $120-140 \mathrm{~g}$, which were kept at a constant temperature $\left(22 \pm 1{ }^{\circ} \mathrm{C}\right)$. They were fed with a maintenance rat diet, had access to water ad libitum and were synchronized by maintenance of controlled environmental conditions (light, temperature, feeding time, etc) for at least 1 week prior to and throughout the experiment. The lighting regimen was $12 \mathrm{~h}$ of light attenuated with $12 \mathrm{~h}$ of darkness. Melatonin and chemical reagents used in this study were purchased from Sigma-Alderich Chemical Co. (St. Louis, MO, USA).

Egypt. J. Rad. Sci. Applic., Vol. 24, No. 1 (2011) 


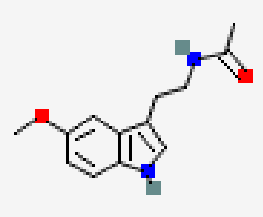

Fig. 1. Melatonin $\left(\mathrm{C}_{13} \mathrm{H}_{16} \mathrm{~N}_{2} \mathrm{O}_{2}\right)$ structure.

\section{Melatonin treatment}

In the present study, a freshly prepared melatonin dose $(10 \mathrm{mg} / \mathrm{kg}$ body wt) was dissolved in $0.5 \mathrm{ml}$ of alchoholic saline as a vehicle (20 part of $0.9 \%$ $\mathrm{NaCl}$ and 1 part of $100 \%$ ethanol v/v) was given to each animal at 10.30 a.m. using stomach tubes according to El-Missiry (2007).

\section{Irradiation technique}

Animals were placed in a specially designed well-ventilated acrylic container and the whole body of the animals was exposed to a dose level of $3 \mathrm{~Gy}$, given at a dose rate of $0.52 \mathrm{~Gy} / \mathrm{min}$ from a biological-irradiator gamma cell-40, ${ }^{137}$ cesium source (Atomic Energy Agency, Canada), belonging to NCRRT, Egypt.

\section{Experimental design}

Control group: Animals received daily $0.5 \mathrm{ml}$ of the vehicle solution for 5 days. Melatonin treated group: Animals received melatonin dosages for 5 days. $\gamma$-irradiated groups: Animals were exposed to a dose level of 3 Gy whole-body $\gamma$-rays, thereafter administrated $0.5 \mathrm{ml}$ of the vehicle. $\gamma$-irradiated \& melatonintreated group: Animals received melatonin dosages for 5 days after radiation exposure.

Animals were sacrificed 6 days after the various treatments and $12 \mathrm{~h}$ after overnight fasting. Blood samples were collected in non-heparinised dry tubes, which were centrifuged and the sera were frozen at $-20{ }^{\circ} \mathrm{C}$ for the following biochemical evaluations. The liver homogenates were prepared in a 10 -fold volume of ice-cold (20mM) tris- $\mathrm{HCl}$ buffer, $\mathrm{pH}$ 7.4.

\section{Biochemical evaluations}

The activities of serum AST, ALP and GGT were estimated according to the methods of Reitman and Frankel (1957), Roy et al. (1970) and Rosalk

Egypt. J. Rad. Sci. Applic., Vol. 24, No. 1 (2011) 
(1975). Lipid peroxidation product, malondialdehyde (MDA), was measured by TBARS method (Ohkawa et al., 1979). The protein carbonylation (PC), a major product of oxidized protein was measured as quantified by Levine et al. (1990). The GSH content was determined according to Beutler (1982). GST activity was performed according Habig et al. (1974). CAT activity was determined as described by Bock et al. (1980). DNA and RNA contents were detected as described by Burton (1956) and Thoresen et al. (1983) methods.

\section{Determination of myeloperoxidase (MPO) activity}

$100 \mathrm{mg}$ of tissue was homogenized in $1 \mathrm{ml}$ ice-cold $0.02 \mathrm{M}$ EDTA, $\mathrm{pH}$ 4.7, for 60 seconds. $1 \mathrm{ml}$ homogenate was centrifuged at 20,000 $\mathrm{g}$ for $15 \mathrm{~min}$ at $+4{ }^{\circ} \mathrm{C}$ to obtain the pellet of the insoluble cellular debris. The pellet was then rehomogenized in an equivalent volume of $0.05 \mathrm{M}$ potassium phosphate buffer, $\mathrm{pH}$ 6.0, containing $0.5 \%$ hexadecyl trimethyl ammonium bromide. This homogenate was centrifuged at $20,000 \mathrm{~g}$ for $15 \mathrm{~min}$ at $+4{ }^{\circ} \mathrm{C}$ and the supernatants were used in the MPO assay by the method of Grisham et al. (1986). Protein assays in the samples were determined by the method of Lowry et al. (1951).

\section{Statistical analysis}

Statistical significance of the data was analysed using Student's $t$-test (Sokal and Rahif, 1981). Data are shown as means \pm SD of 8 rats and the level for statistical significance was $P<0.05$.

\section{Results}

All considered biochemical parameters were not changed significantly after administration of melatonin alone for 5 days (Table 1, 2, $3 \& 4$ ).

TABLE 1. Hepatic levels of TBARS, PC and GSH of male irradiated rats (3 Gy) and the response to post $\gamma$-irradiation treatment with melatonin.

\begin{tabular}{|c|c|c|c|}
\hline Groups & $\begin{array}{c}\text { TBARS } \\
\text { nmol/g protein }\end{array}$ & $\begin{array}{c}\text { PC } \\
\mu \mathrm{mol} / \mathrm{g} \text { protein }\end{array}$ & $\begin{array}{c}\text { GSH } \\
\mathrm{mg} / \mathrm{g} \text { protein }\end{array}$ \\
\hline Control & $351 \pm 26.2$ & $151 \pm 10.1$ & $0.18 \pm 0.013$ \\
\hline Melatonin-treated & $321 \pm 22.5$ & $141 \pm 10.3$ & $0.18 \pm 0.012$ \\
\hline$\gamma$-irradiated & $602 \pm 46.9^{\mathbf{a}, \mathbf{b}}$ & $366 \pm 29.6^{\mathbf{a}, \mathbf{b}}$ & $0.14 \pm 0.011^{\mathbf{a , b}}$ \\
\hline $\boldsymbol{\gamma}$-irradiated \& melatonin-treated & $422 \pm 40.6^{\mathbf{a , b}, \mathbf{c}}$ & $191 \pm 14.5^{\mathbf{a}, \mathbf{b}, \mathbf{c}}$ & $0.16 \pm 0.013^{\mathbf{c}}$ \\
\hline
\end{tabular}

All values are expressed as mean \pm SD of 8 animals.

asignificant when compared with the control group at $P<0.05$.

bignificant when compared with the melatonin-treated group at $P<0.05$.

'Significant when compared with the $\gamma$-irradiated group at $P<0.05$.

Egypt. J. Rad. Sci. Applic., Vol. 24, No. 1 (2011) 
Exposure of rats to $\gamma$-radiation ( $3 \mathrm{~Gy}$ ) resulted in significant increases in TBARS \& PC and a decrease in GSH in the liver tissue 6 days after irradiation comparing with control groups. Daily treatment with melatonin $(10 \mathrm{mg} / \mathrm{kg}$ body wt) for 5 days post irradiation (3 Gy) significantly modulated these radiation-induced changes in TBARS, PC and GSH levels in the liver comparing with irradiated groups (Table 1).

TABLE 2. Hepatic enzymes activities of GST, CAT and MPO of male irradiated rats $(3 \mathrm{~Gy})$ and the response to post $\gamma$-irradiation treatment with melatonin.

\begin{tabular}{|c|c|c|c|}
\hline Groups & $\begin{array}{c}\text { GST } \\
\mu \text { mol/g protein }\end{array}$ & $\begin{array}{c}\text { CAT } \\
\text { mmol/g protein }\end{array}$ & $\begin{array}{c}\text { MPO } \\
\text { U/g tissue }\end{array}$ \\
\hline Control & $18.7 \pm 1.12$ & $4.5 \pm 0.31$ & $1.1 \pm 0.07$ \\
\hline Melatonin treated & $19.2 \pm 1.11$ & $4.1 \pm 0.29$ & $1.1 \pm 0.05$ \\
\hline$\gamma$-irradiated & $12.3 \pm 1.06^{\mathbf{a}, \mathbf{b}}$ & $6.7 \pm 0.44^{\mathbf{a}, \mathbf{b}}$ & $2.4 \pm 0.14^{\mathbf{a}, \mathbf{b}}$ \\
\hline$\gamma$-irradiated \& melatonin-treated & $16.1 \pm 1.09^{\mathbf{a}, \mathbf{b}, \mathbf{c}}$ & $5.1 \pm 0.53^{\mathbf{a}, \mathbf{b}, \mathbf{c}}$ & $1.2 \pm 0.06^{\mathbf{a}, \mathbf{b}, \mathbf{c}}$ \\
\hline
\end{tabular}

Legends as in Table 1.

In livers of irradiated groups (3 Gy), GST activity was significantly inhibited comparing with control group. On the other hand, CAT and MPO activities were significantly increased comparing with control groups. Melatonin-treatment modulated hepatic GST and maintained CAT and MPO activities within the control levels (Table 2). In 3 Gy-irradiated groups, there were significant decreases in hepatic DNA and RNA contents comparing with control groups. Daily treatment with melatonin for 5 days following irradiation showed significantly higher DNA and RNA content in the liver of $\gamma$-irradiated \& melatonintreated groups than irradiated rats (Table 3).

TABLE 3. Hepatic contents of DNA and RNA of male irradiated rats $(3 \mathrm{~Gy})$ and the response to post $\gamma$-irradiation treatment with melatonin.

\begin{tabular}{|c|c|c|}
\hline Groups & $\begin{array}{c}\text { DNA } \\
\mathrm{mg} / \mathrm{g} \text { protein }\end{array}$ & $\begin{array}{c}\text { RNA } \\
\mathrm{mg} / \mathrm{g} \text { protein }\end{array}$ \\
\hline Control & $21.6 \pm 1.41$ & $6.9 \pm 0.17$ \\
\hline Melatonin treated & $21.1 \pm 1.32$ & $6.8 \pm 0.19$ \\
\hline $\boldsymbol{\gamma}$-irradiated & $15.2 \pm 1.01^{\mathbf{a}, \mathbf{b}}$ & $4.1 \pm 0.12^{\mathbf{a}, \mathbf{b}}$ \\
\hline$\gamma$-irradiated \& melatonin-treated & $18.3 \pm 1.14^{\mathbf{a}, \mathbf{b}, \mathbf{c}}$ & $5.5 \pm 0.18^{\mathbf{a , b}, \mathbf{c}}$ \\
\hline
\end{tabular}

Legends as in Table 1.

The activities of AST, ALP, and GGT in serum showed a significant rise at the $6^{\text {th }}$ day following $\gamma$-irradiation comparing with control groups. The treatment with melatonin after irradiation displayed significant amelioration in the elevation of these enzyme activities in serum comparing with irradiated groups (Table 4).

Egypt. J. Rad. Sci. Applic., Vol. 24, No. 1 (2011) 
TABLE 4. Serum activities of AST, ALP and GGT of male irradiated rats (3 Gy) and the response to post $\gamma$-irradiation treatment with melatonin.

\begin{tabular}{|c|l|c|c|}
\hline Groups & \multicolumn{1}{|c|}{ AST } & ALP & GGT \\
& $\mathrm{U} / \mathrm{L}$ & $\mathrm{U} / \mathrm{L}$ & $\mathrm{U} / \mathrm{L}$ \\
\hline Control & $8.6 \pm 0.19$ & $52 \pm 1.3$ & $30 \pm 1.4$ \\
\hline Melatonin treated & $8.6 \pm 0.22$ & $50 \pm 1.4$ & $31 \pm 1.3$ \\
\hline$\gamma$-irradiated & $19.8 \pm 1.11^{\mathbf{a}, \mathbf{b}}$ & $113 \pm 2.2^{\mathbf{a}, \mathbf{b}}$ & $49 \pm 1.7^{\mathbf{a}, \mathbf{b}}$ \\
\hline $\boldsymbol{\gamma}$-irradiated \& melatonin-treated & $13.1 \pm 0.88^{\mathbf{a}, \mathbf{b}, \mathbf{c}}$ & $84 \pm 1.7^{\mathbf{a}, \mathbf{b}, \mathbf{c}}$ & $39 \pm 1.5^{\mathbf{a}, \mathbf{b}, \mathbf{c}}$ \\
\hline
\end{tabular}

Legends as in Table 1.

\section{Discussion}

The biological consequences of ionising-radiation are attributable to chemical changes in biological molecules as a result of energy absorption (Reiter et al., 2004). The generation of the reactive oxygen metabolites plays an important role in the pathogenesis of irradiation-induced tissue injury (Agrawal et al., 2001). $\gamma$-rays induces both an exponential burst of ROS from cells and an exponential increase in intracellular $\mathrm{Ca}^{2+}$ levels (Claro et al., 2008), the exponential increase of both oxidative stress and $\mathrm{Ca}^{2+}$ influx causes a massive, sudden cell death (Liu et al., 2011). Blockade of any of these steps is sufficient to prevent cell death (Tan et al., 2001 ${ }^{\mathrm{a}}$ ).

In the present study, TBARS, PC and GSH levels in the liver altered in $\gamma$ irradiated group comparing with control and melatonin treated groups in agreement with results report by El-Missiry et al. (2007). However, melatonin treatment after irradiation markedly restored TBARS and PC levels. In addition, it maintained hepatic GSH level was maintained close to the control level and showed insignificant changes compared to control and melatonin groups. In contrast, intra-peritoneal melatonin $(10 \mathrm{mg} / \mathrm{kg})$ administrated to rats after whole body gamma-irradiation (6 Gy), resulted in no changes in GSH content in liver tissue (Bhatia and Manda, 2003).

Reduction in the amount of lipid peroxidation products and elevation in GSH level due to melatonin treatment suggested that melatonin could scavenge the free radicals formed during oxidative stress. GSH with its sulfhydryl-group functions in the maintenance of sulfhydryl-groups of other molecules (especially proteins), as a catalyst for disulfide exchange reactions, and in the detoxification of foreign compounds, hydrogen peroxide and free radicals. When GSH acts as a reducing agent, its SH becomes oxidized and forms a disulfide link with other molecules of GSH (Bhatia and Manda, 2004).

Egypt. J. Rad. Sci. Applic., Vol. 24, No. 1 (2011) 
The present study demonstrates that whole body $\gamma$-irradiation (3 Gy) significantly decreased hepatic GST activity in comparison to controls but melatonin treatment post-irradiation significantly countered radiation-induced decrease in the activity of this enzyme in the liver. A significant decrease in hepatic GST activity was recorded after exposure to 3.5 Gy (Sridharan and Shyamaladevi, 2002). Melatonin enhanced the activity of GST in the livers of the $\gamma$-irradiated \& melatonin-treated group. This is supported by the report of Reiter et al. (2001) that melatonin bound to DNA. Thus, it is proposed that GST might be influenced by melatonin. Taken together, these findings support the conclusion that melatonin offers radioprotection by modulating hepatic GST activity.

On the other hand, CAT and MPO activities were significantly increased comparing with control groups. Increased CAT activity is probably related to the inability of the cell to cope with overproduction of $\mathrm{H}_{2} \mathrm{O}_{2}$ or $* \mathrm{OH}$ (Weiss et al., 2003). Oxidative injury of the colon is accompanied with neutrophil infiltration in both early and later phases after irradiation, whereas contribution of neutrophils to the irradiation injury of the liver occurs at the later phase (Sener et al., 2004). Melatonin-treatment modulated hepatic GST and maintained CAT and MPO activities within the control levels. CAT is maintained within control level by post-treatment with melatonin, indicating controlled $\mathrm{H}_{2} \mathrm{O}_{2}$ generation in the liver or it's scavenging directly by melatonin (Tan et al., 2000). In addition, melatonin treatment, suppresses radiation-induced elevation in the hepatic MPO activity.

The major forms of cellular damage induced by radiation are DNA damage, lipid peroxidation, and protein oxidation. The present study demonstrates significant decreases in hepatic DNA and RNA contents comparing with control groups. Ionising radiation generates ROS as a result of water radiolysis. These ROS can induce oxidative damage to vital cellular molecules and structures including DNA, lipids, proteins, and membranes (Cadet et al., 2004). Melatonin mitigated the loss of DNA and RNA from rat liver in accordance with the El-Missiry et al. (2007) report.

The present study demonstrates as well a significant increase in serum AST, ALP and GGT activities after radiation exposure. GGT is a key enzyme in the catabolism of GSH (Lee et al., 2002). It has been reported that the extra cellular cleavage of GSH by GGT induces the production of ROS, suggesting that GGT plays a pro-oxidant role (Lee et al., 2004). Melatonin treatment 
stimulates several antioxidants that raise the total antioxidant capacity of the body (Reiter et al., 2004). Accordingly, melatonin might reduce serum GGT level to exert its antioxidant effect. Gamma-radiation elevates serum AST and ALP level in accordance with other studies (Bhatia and Manda, 2004). The present result demonstrates that melatonin treatment after irradiation ameliorates oxidative stress evidenced by decreased AST and ALP activities the liver.

Melatonin is a potent antioxidant, which can exert its action directly or indirectly (Majsterek et al., 2005). In addition to its direct free radical scavenging action, melatonin antioxidant capacity includes the indirect effect of upregulating several antioxidative enzymes and down-regulating pro-oxidant enzymes (Storr et al., 2002). There is evidence that melatonin acts not only as a hormone but also as a tissue factor (Pandi-Perumal et al., 2006). Additionally, melatonin is an antioxidant nutrient. Although its redox properties are difficult to preserve in food, it has been suggested that certain of its metabolites, especially a substituted kynuramine formed by oxidative pyrrole-ring cleavage, may be stable enough to serve as a dietary supplement without a significant loss of its antioxidant effects (Hardeland and Pandi-Perumal, 2005). Receptorindependent actions of melatonin biology are the array of receptor-independent activities, which operates as a potent cytoprotector and/ or metabolic modulator in many different biological systems (Tan et al., 2007).

\section{Conclusion}

In conclusion, melatonin has clear antioxidant properties and is likely to be a valuable drug for mitigating radiation induced oxidative stress. These findings indicate that melatonin supplementation may be beneficial postradiotherapy. Such application awaits further investigations to be undertaken.

\section{Recommendations}

It may be reasonable to use melatonin with adjusting the dose to achieve the best radio-mitigating effect with as few side effects as possible. Before employment, it should be extensively tested in vitro and in vivo models, using the same and other biomarkers for different radiation exposure levels.

\section{References}

Agrawal, A., Chandra, D. and Kale, R. K. (2001) Radiation induced oxidative stress. II. Studies in liver as a distant organ of tumor bearing mice. Mol. Cellul. Biochem., 224, 9.

Egypt. J. Rad. Sci. Applic., Vol. 24, No. 1 (2011) 
Ahlersova, E., Pastorova, B., Kassayova, M., Ahlers, I. and Smajda, B. (1998) Reduced pineal melatonin biosynthesis in fractionally irradiated rats. Physiol. Res., 47, 133.

Beutler, E., 1982. Red cell metabolism. In: Butler, E. (Ed.), A Manual of Biochemical Methods. Grune and Stratton, New York, p. 137.

Bhatia, A. L. and Manda, K. (2003) Melatonin against radiation induced free radicals: a study on tissues of Swiss albino mice. 12. Quadrennial Cong. of the Int. Assoc. for Rad. Res., Brisbane (Australia) 17-22 Aug, p. 343.

Bhatia, A. L. and Manda, K. (2004) Study on pre-treatment of melatonin against radiationinduced oxidative stress in mice. Environ. Toxicol. Pharmacol., 18, 13.

Bock, P.P., Karmer, R., Paverka, M., 1980. A simple assay for catalase determination. Cell Biol. Monogr. 7, 44.

Burton, K. (1956) A study of the conditions and mechanism of the diphenylamine reaction for the colorimetric estimation of deoxyribonucleic acid. Biochem. J. 62, 315 .

Cadet, J., Bellon, S., Douki, T., Frelon, S., Gasparutto, D., Muller, E., Pouget, J. P., Ravanat, J. L., Romieu, A. and Sauvaigo, S. (2004) Radiation-induced DNA damage: formation, measurement, and biochemical features. $J$. Environ. Pathol. Toxicol. Oncol., 23, 33.

Claro, S., Oshiro, M., Freymuller, F., Katchburian E, Kallas E., Cerri, P., Ferreira, A. (2008) $\gamma$-Radiation induces apoptosis via sarcoplasmatic reticulum in guinea pig ileum smooth muscle cells. Eur. J. Pharmacol., 590, 20.

El-Massry, F. S. (2005) Early prophylactic and treatment role of melatonin against certain biochemical disorders in irradiated rats. Isotop. Rad. Res., 37, 479.

El-Missiry, M. A, Fayed, T. A., El-Sawy, M. R. and El-Sayed, A. A. (2007) Ameliorative effect of melatonin against gamma-irradiation-induced oxidative stress and tissue injury. Ecotoxicol. Environ. Safety, 66, 278.

Esposito, E., Iacono, A., Muia, C., Crisafulli, C., Raso, G., Bramanti1, P., Meli, R. and Cuzzocrea, S. (2008) Signal transduction pathways involved in protective effects of melatonin in C6 glioma cells. J. Pineal Res., 44, 78.

Grisham, M. B., Hernandez, L. A. and Granger, D. N. (1986) Xanthine oxidase and neutrophil infiltration in intestinal ischemia. Am. J. Physiol., 251, G567.

Habig, W. H., Pabst, M. J. and Jakoby, W. B. (1974) Glutathione-S-transferase the first enzyme step in mercapturic acid formation. J. Biol. Chem., 1, 7139.

Hannig, J., Zhang, D., Canaday, D. J., Beckett, M. A., Astumian, R. D., Weichselbaum, R. D. and Lee, R. C. (2000) Surfactant sealing of membranes permeabilized by ionizing radiation. Rad. Res., 154, 171.

Hardeland, R. and Pandi-Perumal, S. R. (2005) Melatonin, a potent agent in antioxidative defense: Actions as a natural food constituent, gastrointestinal factor, drug and prodrug. Nutr. Metab., 2, 22.

Egypt. J. Rad. Sci. Applic., Vol. 24, No. 1 (2011) 
Karbownik, M. and Reiter, R. J. (2000) Antioxidative effects of melatonin in protection against cellular damage caused by ionizing radiation. Proc. Soc. Exp. Biol. Med., 225, 9.

Lee, D. H., Blomhoff, R. and Jacobs Jr., D. (2004) Is serum gamma glutamyltransferase a marker of oxidative stress? Free Radic. Res., 38, 535.

Lee, D., Ha, M., Kim, J., Gross, M. and Jacobs, D. (2002) g-Glutamyltransferase, alcohol, and blood pressure: a four year followup study. Ann. Epidemiol., 12, 90.

Levine, R.L., Garland, D., Oliver, C.N., Amici, A., Climent, I., Lenz, A.G., Ahn, B.W., Shaltiel, S., Stadtman, E.R., 1990. Determination of carbonyl content in oxidatively modified proteins. Methods Enzymol. 186, 464.

Liu, C., Lin, J., Zhao, L., Yang, Y., Gao, F., Li, B., Cui, J. and Cai, J. (2011) Gamma-ray irradiation impairs dendritic cell migration to CCL19 by downregulation of CCR7 and induction of cell apoptosis. Int. J. Biol. Sci., 7, 168.

Lowry, O., Rosenbraugh, N., Farr, L. and Rondall, R. (1951) Protein measurement with the Folin-phenol reagent. J. Biol. Chem., 183, 265.

Majsterek, I., Gloc, E., Blasiak, J. and Reiter, R. J. (2005) A comparison of the action of amifostine and melatonin on DNA damaging effects and apoptosis induced by idarnbicin in normal and cancer cells. J. Pineal Res., 38, 245.

National Research Council (1996) Public Health Guide for the Care and Use of Laboratory Animals. National Research Council Publications. USA.

Ohkawa, H., Ohishi, N. and Yagi, K. (1979) Assay for lipid peroxides in animal tissues by thiobarbituric acid reaction. Anal. Biochem., 95, 351.

Pandi-Perumal, S. R., Srinivasan, V., Maestroni, G. J. M., Cardinali, D. P., Poeggeler, B. and Hardeland, R. (2006) Melatonin: Nature's most versatile biological signal? FEBS J., 273, 2813.

Reiter, R. J., Tan, D. X., Gitto, E., Sainz, R. M., Mayo, J. C., Leon, J., Manchester, L. C., Vijayalaxm, Kilic, E. and Kilic, U. (2004) Pharmacological utility of melatonin in reducing oxidative cellular and molecular damage. Pol. J. Pharmacol., 56, 159.

Reiter, R. J., Tan, D. X., Manchester, L. C. and Qi, W. (2001) Biochemical reactivity of melatonin with reactive oxygen and nitrogen species; A review of the evidence. Cell Biochem. Biophys., 34, 237.

Reitman, S. and Frankel, S. (1957) A colorimetric method for the determination of serum glutamic oxalacetic and glutamic pyruvic transaminases. Am. J. Clin. Pathol., 28, 56.

Rosalk, S. B. (1975) In: Advances Clinical Chemistry. Academic Press, chap. 17, pp. 53.

Roy, A., Brower, M. and Hayden, J. (1970) Sodium thymolphthalein monophosphate. A new acid phosphatase substrate with greater specificity for the prostate enzyme in serum. Clin. Chem., 17, 1093.

Egypt. J. Rad. Sci. Applic., Vol. 24, No. 1 (2011) 
Sener, G., Atasoy, B. M., Ersoy, Y., Arbak, S., Sengoz, M. and Yegen, B. C. (2004) Melatonin protects against ionizing radiation-induced oxidative damage in corpus cavernosum and urinary bladder in rats. J. Pineal Res., 37, 241.

Slominski1, A., Tobin, D. J., Zmijewski1, M. A., Wortsman, J. and Paus, R. (2008) Melatonin in the skin: synthesis, metabolism and functions. Trends in Endocrinol, Metabol., 19, 17.

Sokal, R. and Rahfif, F. J. (1981) $2^{\text {nd }}$ Ed., Freeman, W.H. Company, San Francisco.

Sridharan, S. and Shyamaladevi, C. S. (2002) Protective effect of N-acetylcysteine against gamma ray induced damages in rats-biochemical evaluations. Indian J. Exp. Biol., 40, 181.

Storr, M., Koppitz, P., Sibaev, A., Saur, D., Kurjak, M., Franck, H., Schusdziarra, V. and Allescher, H. D. (2002) Melatonin reduces non-adrenergic, noncholinergic relaxant neurotransmission by inhibition of nitric oxide synthase activity in the gastrointestinal tract of rodents in vitro. J. Pineal Res., 33, 101.

Tan S., Schubert D. and Maher P. (2001 $\left.{ }^{\mathrm{a}}\right)$ Oxytosis: a Novel Form of Programmed Cell Death. Curr. Topics Med. Chem., 1, 497-506.

Tan, D. X., Manchester, L. C., Burkardt, S., Sainz, R. M., Mayo, J. C., Kohen, R., Shohami, E., Huo, Y. S., Hardeland, R. and Reiter, R. J. (2001) N-acetyl$\mathrm{N}$-formyl-5-methoxyknuramine, a biogenic amine and melatonin metabolite, functions as a potent antioxidant. FASEB J., 15, 2294.

Tan, D. X., Manchester, L. C., Reiter, R. J., Plummer, B. F., Linson, J., Weintraub, S. T. and Qi, W. (2000) Melatonin directly scavenges hydrogen peroxide: a potentially new metabolic pathway of melatonin biotransformation. Free Radical Biol. Med., 29, 1177.

Tan, D. X., Manchester, L. C., Terron, M. P., Flores, L. J. and Reiter, R. J. (2007) One molecule, many derivatives: a never-ending interaction of melatonin with reactive oxygen and nitrogen species? J. Pineal Res., 42, 28.

Thoresen, S.S., Clayton, J.R., Dortch, Q.F., Ahmed, S.L., 1983. A rapid technique for the determination of RNA and DNA in marine phytoplankton. J. Plankton Res., 5, 253.

Weiss, J. F., Michael, R. and Landauer, M. R. (2003) Protection against ionizing radiation by antioxidant nutrients and phytochemicals. Toxicol., 189, 1.

Zahran, A. M., Azab, Kh. Sh. and Abbady, M. I. (2006) Modulatory role of allopurinol on xanthine oxidoreductase system and antioxidant status in irradiated rats. Egypt. J. Rad. Sci. Applic., 19, 371.

(Received: 13/07/2011;

accepted: 28/09/2011)

Egypt. J. Rad. Sci. Applic., Vol. 24, No. 1 (2011) 


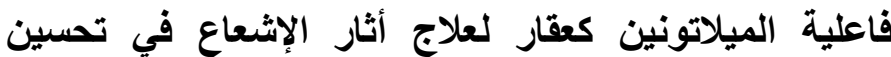

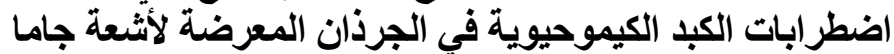

\author{
نعمة محمد الفاتح و الهام الثامي

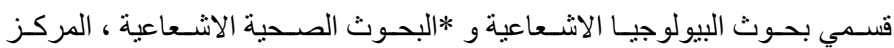

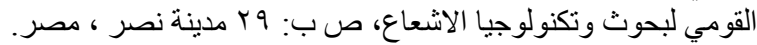

\begin{abstract}
يتميز الميلاتونين بتأثيره المانع لضرر التأكسد علي العديد من الأنسجة

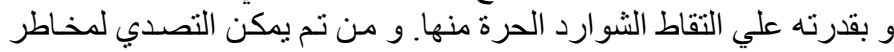

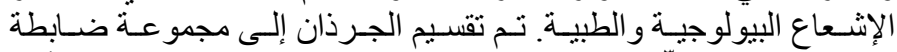

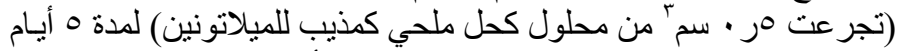

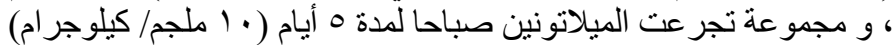

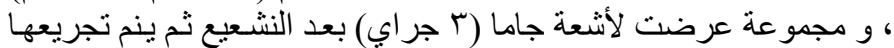

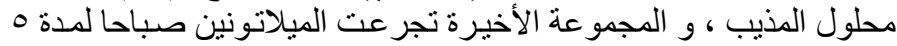

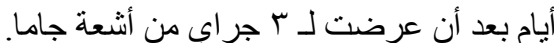

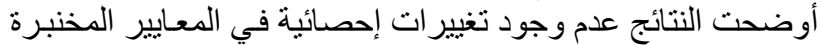

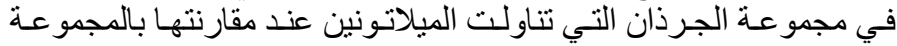

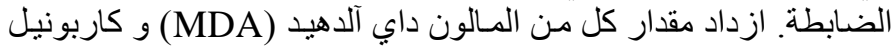

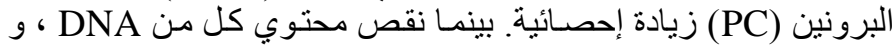

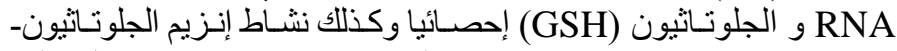

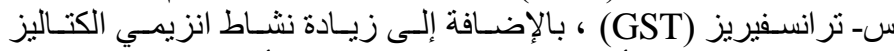

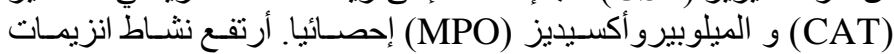

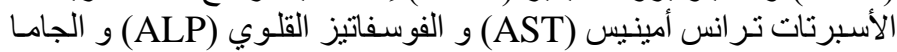

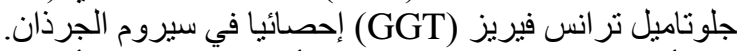

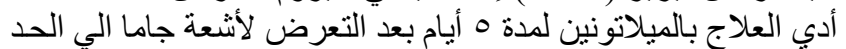

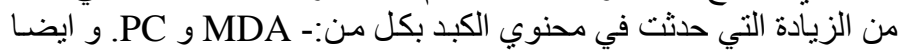

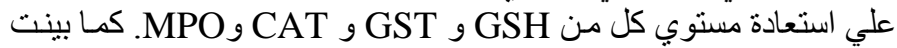
المعالجة بالميلاتونين بعد التعرض لأنشعة جامـا وجود زيادة إحصائية في

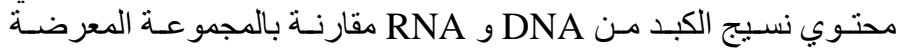

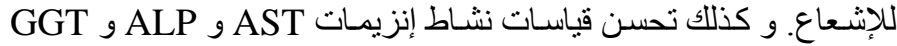

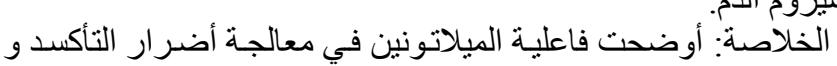

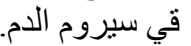

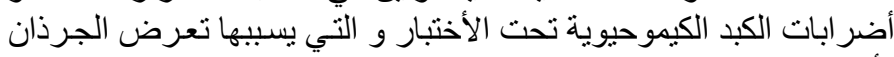

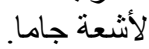

Egypt. J. Rad. Sci. Applic., Vol. 24, No. 1 (2011) 